
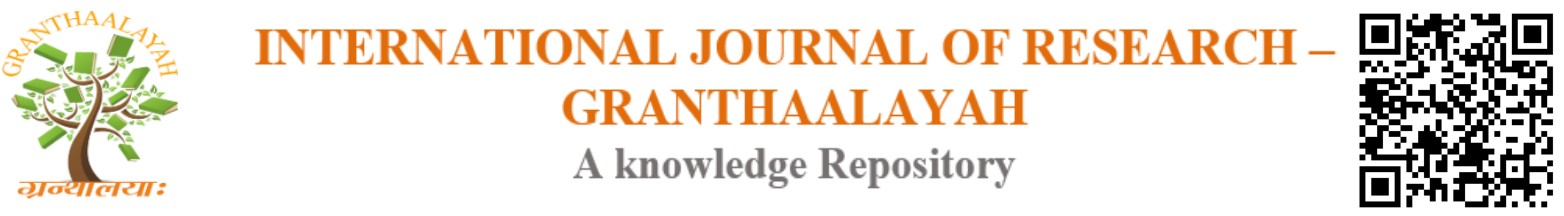

Science

\title{
ASSESSMENT THE RESPONSE OF SAGITTARIO ITALIAN WHEAT VARIETY FOR DIFFERENT CONCENTRATIONS OF ORGANIC FERTILIZERS IN MANY SPRAYING DATES
}

\author{
Ibraheem M.Aliyas ${ }^{1}$, Salem A.Hassen ${ }^{2}$, Hasan Mohsen Neamah ${ }^{3}$ \\ 1, 2, 3 Northern Technical University / Technical Institute of Mosul, Iraq
}

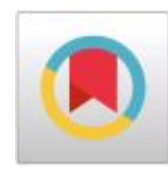

\begin{abstract}
Considers Bio-fertilizer eco-friendly, characterize by their high importance in improve the chemical, physical and biological traits of soil was better from chemical fertilizer Where the latter causes negative effects on biosphere. The study was conducted to assessment the response of Wheat of Sajittario variety (W. S .V) for two concentration levels of Fito Alg organic fertilizer(F.A.O.F) in three spraying dates and their effects on the vegetative growth and yield properties by using the randomized complete block design (RCBD) with three replications.The research was conducted in Mosul city within the province of Nineveh / Iraq at the agrarian season 2014 to study the response of (W. S .V) for two concentrations of (F.A.O.F) were (a1) 2 $\mathrm{ml} / \mathrm{L}$ and (a2) $4 \mathrm{ml} / \mathrm{L}$ in three spraying dates (b1) 23/2, (b2) $2 / 3$ and (b3) $9 / 3$, which sprayed in tillering stage on vegetative growth, for studying their effects on the following properties; plant height $\mathrm{cm}$, tillers number/plant, dry biological weight ( ton/ h), seeds number/ spike, weight of 1000 seeds gm, straw weight (ton/ h) and total yield (ton/ h). By using the randomized complete block design (RCBD) with three replications. Results showed that variance analysis of the concentration of (F.A.O.F) with spraying dates were have significant effect at 0.05 probability level in the following characteristics; tiller number, weight of 1000 seed and yield ,also have significant effect at 0.01 probability level only in spike seeds number, others properties were non-significant at both $0.05,0.01$ levels as table (2). Showed the first spraying date significant effect at 0.05 probability level their superior from others in weight 1000 seed and spike seeds number where was same effected with two others in dates of spraying as in table(3). Showed both concentrations the same effect in all of the traits at 0.05 levels. Where the first concentration had high value than both others concentrations as in table (4). The interaction effect between spraying dates and concentrations of (F A O F) on vegetative growth and yield characters for (W. $\mathrm{S} . \mathrm{V})$, where all vegetative and yield properties where the yield reached $4.86(\mathrm{to} / \mathrm{h})$. That indicates, to response the variety to (F. A O. F) by suitable concentration $2 \mathrm{ml} / 1$ and fit the date of spraying 23/02 (a1b1) as in table (5), addition for good dominant environmental conditions in the study region, as well as the good genetic traits in the variety.
\end{abstract}

Keywords: Wheat; Bio-fertilizer; Fito Alg; Sagittario; Sustainable Agriculture.

Cite This Article: Ibraheem M.Aliyas, Salem A.Hassen, and Hasan Mohsen Neamah. (2017). "ASSESSMENT THE RESPONSE OF SAGITTARIO ITALIAN WHEAT VARIETY FOR 
DIFFERENT CONCENTRATIONS OF ORGANIC FERTILIZERS IN MANY SPRAYING DATES." International Journal of Research - Granthaalayah, 5(11), 271-278. https:// doi.org/10.29121/granthaalayah.v5.i11.2017.2353.

\section{Introduction}

Problem review : In present increased the global challenges, including food security due to environmental crises, such as global warming, water shortages and land degradation, where countries are undernourished, as in some Asian and African countries, this requires the attention of researchers to address this challenge by following new agricultural techniques to maintain the factors of production from degradation and positive adaptation to the factors of sustainable production in the management of agricultural soils and crops as in the wheat plant, which is an important strategic crop is the first degree in providing people with food energy, advantages of organic fertilizers were enhance the bio-mass production and grain yield by $10-20 \%$, Is cheap and can help to reduce the consumption of chemical fertilizers, provide nitrogen directly to the plant and soluble phosphorus also strengthen the plant because of the release of hormones, vitamins, Oxen's etc., improve soil properties and maintain its fertility.

Introduction: The wheat (Triticum aestivum) consider winter cereal crops belong to (Poaceae or Graminae) family,being planting on a widely in the world an in terms of its importance comes of consumed in first grade and representative of essential pillar for food security in the world, including Iraq which suffers from shortage of food. Iraq consumptive more than 3 million ton/yearly by import, expected the gap between the wheat production and the import will increase on 2020 to reach 3.316.751 ton. This requires the innovation of advanced technical methods interacting with the biosphere in a harmonize state [Salem and et al 2017]. The total cultivated area of wheat in Iraq at 2016 was 3,697,200 dunum and the production was 3,052,900 ton by a rate of $826 \mathrm{~kg} /$ dunum[1]. Wheat planting a widely form in the world an in terms of its consume importance comes in first grade and representative the essential pillar for food security in the word, including Iraq which suffers from shortage of food, [Hasan 2017]. The wheat considers first grain crop in worlds in terms of cultivated area and nutritional value is the main food for most people of the world, Wheat plays an important role in the development of ancient world civilizations and throughout the ages, most historians believe that origin of wheat is southwest Asia. Wheat plays a strategic role in the area of food security. its food importance is flour using to produce bread that is indispensable to most people of the world, as well as utilize its flour in manufacture of noodles, biscuits, desserts and pastries also its grains produce bulgur, semolina in a some regions of the world. The hay is secondary product used as animal feed, cultivated area is dependent on rainfall water, rain the sole source of irrigation .In Iraq from year to year uses the chemical fertilizers despite some benefits sometimes but have negative effects when the precipitation is higher than the common average, this leads to being washed nitrogen fertilizer to groundwater and their pollution [Zenter et al1996]. Also when the rainfall be reduced and using Chemical fertilizers lead to greatly reduced productivity and high of soil salinity (Campbell et al 1990). Therefore, due to the addition of chemical fertilizers and the irregularity of their rainfall causes the use of chemical fertilizers many risks, which encourages the search for the use of organic fertilizers in agriculture, where the organic fertilizer supply a nutrient to plants, also improves the physical, chemical and biological properties of the soil, thus increase its ability to retain rainwater therefore being a natural source eco-friendly. from the factors which effects on the growth and production of wheat the amount of rainfall, its intensity and 
distribution of rain during the growing season. In addition of the availability of rain water in some regions, consider fertilization is one of the most influential factors in wheat production [Mizyed g Abu Qaoud1998]. It has been found that the use of organic fertilizers has a role in improving soil texture, increasing the soil's ability to retain water and nutrients, reduce the capacity of wind and water on the soil erosion, as well as encourage growth of microorganisms [Michael 1999]. Found the best amount of organic fertilizer where addition 10 ton / $\mathrm{h}$ in Wheat gave increased in production 14\% [Badaruddin 1999]. In study was the continuously for 13-year for organic fertilizer use on Wheat yield in black soils in China showed their result the superior of organic fertilizer on chemical fertilizer. Finally, it has been found in many studies the use of organic methods in agriculture was positive affected in the soil as it increased the organic matter and the amount of nitrogen available. Traditional Chinese farming was based on efficient utilization and recycling of natural resources. The increasing quest for food by the growing human population led to an increase of $\mathrm{N}$ (and $\mathrm{P}$ ) fertilizer use, unbalanced nutrition and decreasing resource use efficiency. In study the results showed that applications of Wheat plant with green manure kind contributed to increase the benefit efficiency of nitrogen [Willem B. Hoogmoed, Udo D. Perdok, Oene Oenema, 2007]. That the addition of organic manure found increased nitrogen absorption efficiency and improved the grain production [Diego J. et al, 2015]. Organic fertilizers plays an important role in enhancing crop productivity. However, chemical fertilizers are expensive, non-eco-friendly, causing reduces of micro biotic activity in soil and is hazardous to health. Therefore, the use of bio fertilizers is desirable as they are natural biodegradable, more effective than chemical fertilizers. Bio fertilizers consist from plant residue by the result some of micro-organisms activation by convert it to simple compound, bio fertilizers help to increase quality of the soil by providing nutrients and protect the ecosystem from degradation. The micro-organisms present in bio fertilizers are important because they produce nitrogen, potassium, phosphorus and other nutrients required for benefit of the plants. Most bio fertilizers also secrete hormones like; auxins, cytokinins, biotins and vitamins which are essential for plant growth. bio fertilizers gives protection to plant by secreting antibiotics which are effective against many plant pathogens, bio fertilizers also protect plant from salinity and dry stress, bio fertilizers are inexpensive and safe matter which provide a wide scope for researchers in the areas of organic farming studying and development of stress-free environment. Overall, the significant role of bio fertilizers is plant growth in better form with high productivity and protection against some stresses makes them a vital and powerful tool for organic and sustainable agriculture. From the other bio fertilizers which are utilize in many crops were Azotobacter, Azospirillum, Rhizobium, Blue green algae, microorganisms, Mycorrhizae and Vermicomposting. These achieves sustainable agrarian development,

Notice: Dunum $=50 \times 50 \mathrm{~m}=1 / 4$ hectare

\section{Materials and Methods}

This study was conducted in the season of 2013/2014 of Mosul city which distance $400 \mathrm{~km}$ from Baghdad city center in Nineveh Governorate territory within the Plant production department in Technical Institute/Mosul of Iraq, where clay soil, To evaluate the impact of two levels concentration from Fito Alg bio-fertilizer; (-) on vegetative growth and productivity of Sagittario Wheat variety. Prepared the experiment land by soil management equipment as; plowing, smothering and leveling. Cultivated the Wheat variety in $15 / 11$ by seed rates $160 \mathrm{~kg} /$ hectare in 
rows by distance $15 \mathrm{~cm}$ between rows, area of plot $12 \mathrm{~m}^{2}$, was fertilized the plants by biofertilizer (Fito Alg) by two concentration (a1) $2 \mathrm{ml} / \mathrm{L}$ and (a2) $4 \mathrm{ml} / \mathrm{L}$ in three spraying dates (b1) 23/2, (b2) $2 / 3$ and (b3) $9 / 3$ in tiller stage, water demand depending on rainfall. The varieties of Wheat were planted by using the complete randomized block design (CRBD) with three replications. The samples were taken by area $1 \mathrm{~m}^{2}$ using a wooden square by dimensions $1 \mathrm{x} 1 \mathrm{~m}$ from the middle of each plots which harvested in 9/5/2014. The data recorded for each experimental units for study the following characteristics; plant height $\mathrm{cm}$,tiller number, number of seeds / spike, weight of 1000 grain/ gm, biological yield Ton/h, weight of straw ton/h and seed yield Ton/h. The data were statistically analyzed according to (CRBD) design and compared the mathematical means due to Duncan test at probability levels $5 \%$ and $1 \%$ by depending to text book [Alrawi, 1980].The Fito Alg Ecklonia maxima contain cytokinin, oligomeric alginate potassium, betaine, mannitol, polysaccharide, iodine, microelement and alginic polyphenol etc. It has remarkable functions in promoting cell division, anti-stress, antiplant diseases and insect pests, increasing yield, regulating growth and improving soil condition and so on meanwhile, it can comply with requirement of producing green organic food because of its high efficiency and safety[Jump up Anderson, R. J.; M. D. Rothman; A. Share; H. Drummond, 2006].

\section{Results and discussion}

Mosul has a hot semi-arid climate verging on the Mediterranean climate, with extremely hot dry summers and moderately wet, relatively cool winters. Table (1) clears climate elements. From the climate and environmental analysis clear that the rain falling in the winter and spring at month of October and to the end of May with a chance of snow in winter, the rate of rainfall precipitation in the Mosul area about $363.6 \mathrm{ml} /$ year as annually average of high temperature reached $28.22{ }^{\circ} \mathbf{C}$, annually average of low temperature reached $11.67{ }^{\circ} \mathbf{C}$., The organic farming seems to be more harmonize with ecosystem, which was an important techniques to achieve sustainability of natural resources and environment protection. It is a productivity system which favors optimum use of organic materials as; crop residue, animal residue, legumes, farm wastages, natural growth regulators, bio-pesticides and discourages use of chemical products for maintaining soil productivity and fertility and pest management under conditions of sustainable natural resources and healthy environment. In this paper is focused conducting to organic farming as a alternate to traditional farming for achieve sustainable production for crops. There has been intensive chemical fertilizer uses for the last four decades. Where polluting effects of fertilizers are being observed now problems in developing countries should be expected in the near future. Some important problems associated in fertilizers pollution were be summarized as below: nitrate pollution, accumulation of heavy metals, Water pollution, biosphere changes. The objective of this study is to review the negative impact of traditional agriculture and compare it with modern agriculture and to promote the organic farming for sustainable crop production. In current the sustainable ecological agriculture has been come one of the essentials in the sustainability production to achieve a food security particularly in wheat crop where it is the main crop in production and occupies of wide lands in world and Iraq with the selection of organic fertilizer with wheat variety of Sagittario, the aim of research how to activation the relationship between environmental factor that represented by organic farming and genetic factor by use the variety of Sagittario Wheat with supplying its nutrient needs by (F.A.O.F) and their reflection on vegetative growth \& yield. Results showed that variance analysis of the 
concentration of (F.A.O.F) with spraying dates were have significant effect at 0.05 probability level in the following characteristics; tiller number, weight of 1000 seed and yield ,also have significant effect at 0.01 probability level only in spike seeds number, others properties were non-significant at both $0.05,0.01$ levels as table (2). Showed the first spraying date significant effect at 0.05 probability level their superior from others in weight 1000 seed and spike seeds number where was same effected with two others in dates of spraying as in table(3). Showed both concentrations the same effect in all of the traits at 0.05 levels. Where the first concentration had high value than both others concentrations as in table (4). The interaction effect between spraying dates and concentrations of (F A O F) on vegetative growth and yield characters for (W. $\mathrm{S}$.V), where all vegetative and yield properties where the yield reached $4.86(\mathrm{to} / \mathrm{h})$. That indicates, to response the variety to (F. A O. F) by suitable concentration $2 \mathrm{ml} / 1$ and fit the date of spraying 23/02 as in table (5), addition for good dominant environmental conditions in the study region, as well as the good genetic traits in the variety. Conclusion that organic fertilizers in both two concentrations with first spraying date were better in all traits of plant. Evaluates the organic farming system better than traditional farming due to improving of all traits of plant in addition of its ecological, economical importance in achievement of sustainable agricultural development. That clears the importance of bio-organic fertilizer systems with respect to their positive effects on all soil properties, soil insect fauna and nutrient flow within the soil, crop health and nutritional value of the crop yield. Crop and Soil Management, farm waste recycling, domestic and Industrial waste recycling, and energy use, food quality, ecological agriculture, integrated farming system,

Table 1: Refers to monthly average of the climate factors in Mosul

Climate data for Mosul

\begin{tabular}{|c|c|c|c|c|c|c|c|c|c|c|c|c|c|}
\hline Month & Jan & Feb & Mar & Apr & May & Jun & Jul & Aug & Sep & Oct & Nov & Dec & Year \\
\hline Record high ${ }^{\circ} \mathbf{C}\left({ }^{\circ} \mathbf{F}\right)$ & $\begin{array}{l}21.1 \\
(70)\end{array}$ & $\begin{array}{l}26.9 \\
(80.4)\end{array}$ & $\begin{array}{l}31.8 \\
(89.2)\end{array}$ & $\begin{array}{l}35.5 \\
(95.9)\end{array}$ & \begin{tabular}{|l|}
42.9 \\
$(109.2)$
\end{tabular} & $\begin{array}{l}44.1 \\
(111.4)\end{array}$ & $\begin{array}{l}47.8 \\
(118)\end{array}$ & \begin{tabular}{|l}
49.3 \\
$(120.7)$
\end{tabular} & $\begin{array}{l}46.1 \\
(115)\end{array}$ & $\begin{array}{l}42.2 \\
(108)\end{array}$ & $\begin{array}{l}32.5 \\
(90.5)\end{array}$ & $\begin{array}{l}25.0 \\
(77)\end{array}$ & $\begin{array}{l}49.3 \\
(120.7)\end{array}$ \\
\hline Average high ${ }^{\circ} \mathbf{C}\left({ }^{\circ} \mathbf{F}\right)$ & $\begin{array}{l}12.8 \\
(55)\end{array}$ & $\begin{array}{l}15.3 \\
(59.5)\end{array}$ & $\begin{array}{l}19.0 \\
(66.2)\end{array}$ & $\begin{array}{l}25.4 \\
(77.7)\end{array}$ & $\begin{array}{l}32.9 \\
(91.2)\end{array}$ & $\begin{array}{l}39.6 \\
(103.3)\end{array}$ & $\begin{array}{l}43.4 \\
(110.1)\end{array}$ & $\begin{array}{l}43 \\
(109)\end{array}$ & $\begin{array}{l}38.7 \\
(101.7)\end{array}$ & $\begin{array}{l}31.2 \\
(88.2)\end{array}$ & $\begin{array}{l}22.3 \\
(72.1)\end{array}$ & $\begin{array}{l}15 \\
(59)\end{array}$ & $\begin{array}{l}28.22 \\
(82.75)\end{array}$ \\
\hline Average low ${ }^{\circ} \mathbf{C}\left({ }^{\circ} \mathbf{F}\right)$ & $\begin{array}{l}2.5 \\
(36.5)\end{array}$ & $\begin{array}{l}3.5 \\
(38.3)\end{array}$ & $\begin{array}{l}6.3 \\
(43.3)\end{array}$ & $\begin{array}{l}10.2 \\
(50.4)\end{array}$ & $\begin{array}{l}15 \\
(59)\end{array}$ & $\begin{array}{l}19.5 \\
(67.1)\end{array}$ & $\begin{array}{l}22.9 \\
(73.2)\end{array}$ & $\begin{array}{l}21.8 \\
(71.2)\end{array}$ & $\begin{array}{l}16.6 \\
(61.9)\end{array}$ & $\begin{array}{l}11.4 \\
(52.5)\end{array}$ & $\begin{array}{l}7 \\
(45)\end{array}$ & $\begin{array}{l}3.3 \\
(37.9)\end{array}$ & $\begin{array}{l}11.67 \\
(53.03)\end{array}$ \\
\hline Record low ${ }^{\circ} \mathbf{C}\left({ }^{\circ} \mathbf{F}\right)$ & $\begin{array}{l}-17.6 \\
(0.3)\end{array}$ & $\begin{array}{l}-12.3 \\
(9.9)\end{array}$ & $\begin{array}{l}-5.8 \\
(21.6)\end{array}$ & $\begin{array}{l}-4.0 \\
(24.8)\end{array}$ & $\begin{array}{l}2.5 \\
(36.5)\end{array}$ & $\begin{array}{l}9.7 \\
(49.5)\end{array}$ & $\begin{array}{l}11.6 \\
(52.9)\end{array}$ & $\begin{array}{l}14.5 \\
(58.1)\end{array}$ & $\begin{array}{l}8.9 \\
(48)\end{array}$ & $\begin{array}{l}-2.6 \\
(27.3)\end{array}$ & $\begin{array}{l}-6.1 \\
(21)\end{array}$ & $\begin{array}{l}-15.4 \\
(4.3)\end{array}$ & $\begin{array}{l}-17.6 \\
(0.3)\end{array}$ \\
\hline $\begin{array}{l}\text { Average precipitation } \\
\text { mm (inches) }\end{array}$ & $\begin{array}{l}62.1 \\
(2.445)\end{array}$ & $\begin{array}{l}62.7 \\
(2.469)\end{array}$ & $\begin{array}{l}63.2 \\
(2.488)\end{array}$ & $\begin{array}{l}44.1 \\
(1.736)\end{array}$ & $\begin{array}{l}15.2 \\
(0.598)\end{array}$ & $\begin{array}{l}1.1 \\
(0.043)\end{array}$ & $\begin{array}{l}0.2 \\
(0.008)\end{array}$ & $\begin{array}{l}0.0 \\
(0)\end{array}$ & $\begin{array}{l}0.3 \\
(0.012)\end{array}$ & $\begin{array}{l}11.8 \\
(0.465)\end{array}$ & $\begin{array}{l}45.0 \\
(1.772)\end{array}$ & $\begin{array}{l}57.9 \\
(2.28)\end{array}$ & $\begin{array}{l}363.6 \\
(14.316)\end{array}$ \\
\hline $\begin{array}{l}\text { Average precipitation } \\
\text { days }\end{array}$ & 11 & 11 & 12 & 9 & 6 & 0 & 0 & 0 & 0 & 5 & 7 & 10 & 71 \\
\hline
\end{tabular}


Table 2: variance analysis for the response of Sagittorio wheat variety for different concentrations of org.fert. in many spraying dates and their both effect on properties of vegetative growth and yield

\begin{tabular}{|l|l|l|l|l|l|l|l|}
\hline S.O.V & $\begin{array}{c}\text { Plant } \\
\text { height } \\
\mathbf{C m}\end{array}$ & $\begin{array}{c}\text { Number } \\
\text { Of tillers } \\
\text { /plant }\end{array}$ & $\begin{array}{c}\text { Biological } \\
\text { dry plant } \\
\text { weight } \\
\text { ton/ h }\end{array}$ & $\begin{array}{c}\text { Weight } \\
\text { of straw } \\
\text { ton/h }\end{array}$ & $\begin{array}{c}\text { 1000 } \\
\text { grain } \\
\text { weight/ } \\
\text { gm }\end{array}$ & $\begin{array}{c}\text { Grain } \\
\text { No./ spike }\end{array}$ & $\begin{array}{c}\text { Grain } \\
\text { yield } \\
\text { ton / h }\end{array}$ \\
\hline Blocks & $\mathbf{8 . 5 6 7}$ & 1.6943 & 0.498 & 0.228 & 0.66 & 6.0555 & 0.0603 \\
\hline $\mathbf{A}$ & $\mathbf{2 . 6 2 3}$ & $* 1.561$ & 5.6082 & 0.3677 & $* 18.000$ & $* * 163.722$ & $* 2.093$ \\
\hline B & $\mathbf{2 . 3 4 7 2}$ & 0.064 & 3.79042222 & 1.306 & 2.000 & 34.7222 & 0.1136 \\
\hline A*B & $\mathbf{0 . 7 7 3 8}$ & 0.1840 & 3.00722 & $* 2.986$ & 8.000 & 40.055 & 1.2133 \\
\hline Error & $\mathbf{3 . 2 6}$ & 0.21 & 4.411 & 0.449 & 2.66 & 14.322 & 0.4550 \\
\hline
\end{tabular}

*And **Significant at probability level $(0,05$ and 0,01$)$ respectively

Table 3: Effect of spraying dates of org.f on vegetative growth and yield characters for sagittorio v.wheat plant

\begin{tabular}{|l|l|l|l|l|l|l|l|}
\hline $\begin{array}{c}\text { Spraying } \\
\text { date }\end{array}$ & $\begin{array}{c}\text { Plant } \\
\text { hight } \\
\text { Cm }\end{array}$ & $\begin{array}{c}\text { n.of } \\
\text { tillers }\end{array}$ & $\begin{array}{c}\text { Dry } \\
\text { weight }\end{array}$ & $\begin{array}{c}\text { Straw } \\
\text { weight }\end{array}$ & $\begin{array}{c}\text { 1000grain } \\
\text { weight }\end{array}$ & $\begin{array}{c}\text { N.og } \\
\text { grainspike }\end{array}$ & $\begin{array}{c}\text { Grain } \\
\text { yield }\end{array}$ \\
\hline A1 & $\mathrm{a} 73.817$ & $\mathrm{a} 2.495$ & $\mathrm{a} 12.650$ & $\mathrm{a} 3.786$ & $\mathrm{a} 36.00$ & $\mathrm{a} 53.500$ & $\mathrm{a} 4.635$ \\
\hline $\mathrm{A} 2$ & $\mathrm{a} 73.267$ & $\mathrm{ab} 2.00$ & $\mathrm{a} 11.098$ & $\mathrm{a} 3.49$ & $\mathrm{~b} 33.00$ & $\mathrm{~b} 46.333$ & $\mathrm{ab3} .933$ \\
\hline A3 & $\mathrm{a} 72.500$ & $\mathrm{~b} 1.47$ & $\mathrm{a} 10.87$ & $\mathrm{~A} 3.29$ & $\mathrm{~b} 33.00$ & $\mathrm{~b} 43.33$ & $\mathrm{~b} 3.458$ \\
\hline
\end{tabular}

Means preceded by similar letters do not differ among them at the level of probability 0.05

Table 4: Effect of concentrations of org.f on vegetative growth and yield characters for sagittorio wheat plant

\begin{tabular}{|c|c|c|c|c|c|c|c|}
\hline $\begin{array}{c}\text { concentration } \\
\text { of org.f }\end{array}$ & $\begin{array}{c}\text { Plant } \\
\text { height } \\
\text { Cm }\end{array}$ & $\begin{array}{c}\text { Number } \\
\text { Of tillers } \\
\text { /plant }\end{array}$ & $\begin{array}{c}\text { Dry plant } \\
\text { weight }\end{array}$ & $\begin{array}{c}\text { Weight } \\
\text { of straw } \\
\text { (ton/h) }\end{array}$ & $\begin{array}{c}\text { 1000 grain } \\
\text { weight/ } \\
\text { gm }\end{array}$ & $\begin{array}{c}\text { N. of } \\
\text { grain per } \\
\text { spike }\end{array}$ & $\begin{array}{c}\text { Grain } \\
\text { yield ton } \\
\text { / h }\end{array}$ \\
\hline b1 & $\begin{array}{c}\text { A } \\
73.556\end{array}$ & $\mathrm{a} 2.050$ & $\mathrm{a} 12.000$ & $\mathrm{a} 3.793$ & $\mathrm{a} 34.33$ & $\mathrm{a} 49.111$ & $\mathrm{a} 4.095$ \\
\hline $\mathrm{b} 2$ & $\begin{array}{c}\mathrm{A} \\
72.833\end{array}$ & $\mathrm{a} 1.930$ & $\mathrm{a} 11.08$ & $\mathrm{a} 3.254$ & $\mathrm{a} 33.66$ & $\mathrm{a} 46.33$ & $\mathrm{a} 3.936$ \\
\hline
\end{tabular}

Means preceded by similar letters do not differ among them at the level of probability 0.05

Table 5: Effect of interaction between spraying dates and concentrations of org.f on vegetative growth and yield characters for sagittorio v.wheat plant

\begin{tabular}{|l|l|l|l|l|l|l|l|}
\hline $\begin{array}{c}\text { Interaction } \\
\text { between } \\
\begin{array}{c}\text { Spraying } \\
\text { dates \& } \\
\text { concretion }\end{array}\end{array}$ & $\begin{array}{c}\text { Plant } \\
\text { height } \\
\text { Cm }\end{array}$ & $\begin{array}{c}\text { N.of } \\
\text { tillers } \\
\text { /plant }\end{array}$ & $\begin{array}{c}\text { Dry } \\
\text { Biological } \\
\text { weight } \\
\text { Ton/h }\end{array}$ & $\begin{array}{c}\text { Weight } \\
\text { of } \\
\text { straw } \\
\text { ton/h }\end{array}$ & $\begin{array}{c}\text { 1000 } \\
\text { grain } \\
\text { weight gm }\end{array}$ & $\begin{array}{c}\text { N. of grain } \\
\text { per spike }\end{array}$ & $\begin{array}{c}\text { Grain } \\
\text { yield }\end{array}$ \\
\hline a1b1 & a 73.90 & a 2.59 & a13.300 & A4.54 & a37.00 & a54.00 & A4.86 \\
\hline
\end{tabular}




\begin{tabular}{|l|l|l|l|l|l|l|l|}
\hline Ab2 & a 73.73 & a 2.40 & a12.000 & Ab4.03 & ab35.0 & a53.00 & A4.41 \\
\hline A2b1 & a 73.50 & ab2.25 & a11.927 & Abc3.89 & ab34.0 & a50.66 & A4.38 \\
\hline A2B2 & a 73.26 & b1.75 & a11.423 & Bc3.03 & ab34.0 & b43.66 & Ab3.89 \\
\hline A3B1 & a 73.03 & b1 150 & a10.773 & Bc2.95 & b32.00 & b43.00 & Ab3.53 \\
\hline A3B2 & b71.73 & b1.45 & a9.823 & C2.70 & b32.00 & b42.00 & B3.02 \\
\hline
\end{tabular}

Means preceded by similar letters do not differ among them at the level of probability 0.05

\section{Recommendations}

- Organic fertilizer constituents prevent soil from erosion and desertification and maintains soil nutrient.

- Organic materials are the filler matter for soil granules that feeds microorganisms by their role for converted to metal elements and humus material.

- Use of organic fertilizers to increase the production of wheat and maintain the environment and organisms from pollution.

- Aadvice to use manure manufactured at levels not exceeding $400 \mathrm{~kg} /$ dunum in Wheat crop.

- Cultivate the varieties of highly production from wheat like Sagittrario and Iba99 in fed rian culture.

- Study some of the problems that are related by techniques of production in Wheat cultivation for the aim of rise their production.

- Organic water holding capacity and thereby helps to maintain the water regime of the soil. Matter through decomposition of residue of plants by micro-organisms serves in produce nitrogen, phosphorus, sulphur and other metals it helps in plant growth.

- It posses considerable.

- It acts as a buffer against in PH of the soil.

- Its dark color contributes to absorption of energy from the sun and heating of the soil.

- It acts as "cement" for connect clay and silt particles together, thus contributing to the crumb structure of the soil and resistance against soil erosion.

- It binds micro-nutrients like metal ions in the soil, that otherwise might be their washing out of the surface soil.

- Humus substance from organic constituents it may act for plant as growth stimulants.

\section{References}

[1] Salem A. Hassen et al ,2017, Effect of Supplemental Irrigation on Vegetative Growth and Yield Properties for Two of Wheat Varieties in Erbil of Iraq, (IJSPR) Issue 88, Volume 31, Number 02,pp.58-61.

[2] Hasan Mohsen Neamah ,2017,ASSESSMENT OF RESPONSE IBA 99 WHEAT VARIETY FOR ZERO TILLAGE UNDER MANY NUTRIENT RATES, International Journal of Current Research Vol. 9, Issue, 08, pp.55451-55455.

[3] Abd- el- Male: Y.. M.Monib. I. Hosuy. S.A Girgis. 1979. Effects of organic matter supplementation on nitrogen transformation in soils. Zentralbl Bakteriol naturwiss 1979.. 134(3) 16-209.

[4] Campell. C.A. R. P. Zentener. H. H. Janzen. And J. D. Beaton. 1990. Crop rotation studies on the Cansdian prairies. Research Branch Agtic. Canada Publ. 184. 
[5] Abu- Qaoud. H.. and Mizyed. n: (2000)1997. The response of three varieties of wheat to nitrogen fertilization. An-Najah University J. Res. Vol:12 55-69.(2000)

[6] Michexel. A. S. 1999. Manure management in Minnesota. University of Minnesota Extension Service.

[7] Bodaruddin. M... Reynolds. M. P.. Adeeb: O. A. A. Wheat management in warn environments. J. Agron. 1999. 91:6. 975-983. 1999.

[8] Alvares. C. E... C. Garcia. And A.E Carracedo, 1988, soil fertilizing and mineral nutrition of an organic banana plantation in Tenerife. Biol. Agric. Hortic. 5:313-323. .

[9] Alvares.C.E..A.E.Carracedo. E.Iglesias. And M. C. Martinez, 1993, Pineapples cultivated by conventional and organic methods in a soil from a banana plantation Biol. Agriv. Horric. 9: 161171.

[10] Al-Rawi Kh. Mahmoud, 1980, "Design and analysis of agricultural experiments", Dep. of Field Crops, Faculty of Agriculture and Forestry, University of Mosul. Iraq.

[11] Jump up Anderson, R. J.; M. D. Rothman; A. Share; H. Drummond (2006). "Harvesting of the kelp Ecklonia maxima in South Africa affects its three obligate, red algal epiphytes". Journal of Applied Phycology. Springer. 18 (3-5): 343-349. Doi:10.1007/s10811-006-9037-7.

[12] Willem B. Hoogmoed, Udo D. Perdok, Oene Oenema, 2007, Crop residue, manure and fertilizer in dry land maize under reduced tillage in northern China: I grain yields and nutrient use efficiencies, Nutrient Cycling in Agro Ecosystem September 2007, Volume 79,Issue 1, pp 1-16.

[13] Diego J. Incl_an, Pierfilippo Cerretti, 2015, Organic farming enhances parasitoid diversity at the local and landscape scales, Journal of Applied Ecology 2015, 52, 1102-1109.

*Corresponding author.

E-mail address: aboesamalnaser@yahoo.com 